\title{
Paternal High-Fat Diet Exposure Induces Adverse Effects on Offspring Health: a Systematic Review of Animal Studies
}

\author{
Mariane dos Santos Gonçalves ${ }^{1}$ \\ http://orcid.org/0000-0001-9267-6873
}

Gabriela dos Santos Perez ${ }^{1}$

http://orcid.org/0000-0001-8860-9571

Luciana de Jesus Dantas Ferreira ${ }^{1}$

https://orcid.org/0000-0002-0073-5643

\author{
Gabriele dos Santos Cordeiro' \\ http://orcid.org/0000-0002-2040-8623 \\ Ricardo David Couto ${ }^{2}$ \\ https://orcid.org/0000-0003-2119-437X
}

\author{
Jairza Maria Barreto Medeiros ${ }^{1^{*}}$ \\ http://orcid.org/0000-0003-3533-7108
}

\section{Lucimeire Santana dos Santos ${ }^{1}$ \\ http://orcid.org/0000-0002-6755-7888}

\begin{abstract}
${ }^{1}$ Federal University of Bahia, School of Nutrition, Department of Nutrition School of Nutrition, Salvador, Bahia, Brazil; ${ }^{2}$ Federal University of Bahia, Faculty of Pharmacy, Department of Clinical and Toxicological Analysis, Salvador, Bahia, Brazil
\end{abstract}

Editor-in-Chief: Paulo Vitor Farago

Associate Editor: Paulo Vitor Farago

Received: 2019.02.28; Accepted: 2020.08.14.

*Correspondence: jmbm@ufba.br; Tel.: +55-71-32837700 (J.M.B.M.).

\section{HIGHLIGHTS}

- The main consequences for the offspring are correlated to metabolic health.

- Paternal exposure to a high-fat diet induces insulin resistance on offspring.

- In female offspring induces increased risks of breast cancer.

- In male offspring induces renal injury and increased triglycerides.

Abstract: This systematic review examined the effects of paternal exposure to a high-fat diet on the likelihood of offspring developing health consequences, including metabolic conditions. While the connection between a mother's diet and offspring health has been well established, our understanding of whether offspring health is affected by a father's diet remains limited. This systematic review was performed according to the Preferred Reporting Items for Systematic reviews and Meta-Analysis (PRISMA) recommendations. The PubMed, Scopus, and Embase electronic databases were searched using combinations of the MESH terms: obesogenic diet, high-fat diet, cafeteria diet, paternal diet, parental diet, programming, paternal effects, and paternal programming. Sixteen studies were selected after assessing articles for eligibility criteria. The main outcomes concerning offspring health related to metabolic disorders. The offspring of fathers exposed to a high-fat diet displayed elevated gene expression and serum levels of leptin, decreased gene expression and serum levels of adiponectin, insulin resistance, glucose intolerance, hyperglycemia, hyperinsulinemia, changes in the transcriptome of pancreatic islet tissues, increased triglycerides, and increased expression of 
lipogenic genes. The available evidence suggests that paternal exposure to a high-fat diet may induce harmful effects on the health of offspring.

Keywords: high-fat diet; paternal imprinting; paternal programming; offspring; rats; mice.

\section{INTRODUCTION}

Western nutritional habits have caused serious consequences in populations where they are widely employed. The increased consumption of calories and saturated fats, alongside low consumption of fruits and vegetables, has favored the emergence of obesity and numerous other diseases related to it $[1,2]$.

Maternal dietary patterns that are high in meals containing large quantities of calories and fat have been shown to increase the risk of offspring developing metabolic syndrome in adulthood [3-5]. Despite the large influence from maternal metabolic programming through specific intrauterine events, half of a progeny's genetic and epigenetic heritage is of paternal origin [3,6].

There is evidence that paternal lifestyle can influence the health of the offspring. Experimental studies on paternal diets have demonstrated effects on embryonic metabolism, fetal growth, and the long-term metabolic health of the offspring, thus revealing the importance of paternal feeding habits on fetal origins of adult diseases [7-11].

Sperm are highly affected by their environment. Paternal factors including body composition, age, lifestyle, and, especially, eating habits can all affect sperm quality. Notably, these changes occur mainly through epigenetic regulation [12,13]. Epigenetic regulation in sperm includes DNA methylation, histone modifications (exchange of somatic histones for specific histones), chromatin modifications (reorganization and condensation), and the remodeling and expression of microRNAs [12,14]. Acquired epigenetic mutations are not corrected during fertilization and, thus, are transferred to the offspring. Therefore, epigenetic regulation strongly influences sperm quality [12-14].

Considering these facts regarding the importance of paternal metabolic programming, this systematic review aims to provide an overview of the effects of a paternal high-fat diet on offspring health.

\section{MATERIAL AND METHODS}

\section{Search strategy}

The systematic review was conducted according to PRISMA guidelines [15]. In July 2019, the electronic databases PubMed, Scopus and Embase were searched using combinations of the following MESH terms: obesogenic diet, high-fat diet, cafeteria diet, paternal diet, parental diet, paternal effects, and paternal programming. The booleans operators "AND" and "OR" were used to cross the terms as follows: (paternal effects OR paternal programming OR paternal diet OR parental diet) AND (obesogenic diet OR high-fat diet OR cafeteria diet). The titles, summaries and complete works identified were then assessed as detailed below.

\section{Study selection}

Two independent reviewers each selected articles after an initial reading of their titles and abstracts; in cases of selection disagreement, a third reviewer was used to verify if the study in question was eligible. Subsequently, a full analysis of each selected article was performed by reviewers. Articles were selected for data collection using a set of previously chosen criteria, comprising: (1) original experimental studies using mice or rats; (2) articles in the English language; (3) full texts available; (4) studies published between the years 2009 and 2019; and (5) studies involving solely a paternal high-fat diet. Exclusion criteria for study selection consisted of: (1) studies examining more than one type of intervention (e.g. high protein, physical exercise, etc); (2) non-original studies, review articles, and clinical studies involving humans or animals other than mice and rats; (3) repeated studies; and (4) in vitro studies.

\section{Data extraction and quality assessment}

Two authors, working independently, used a standard data extraction form to collect the relevant study information, which included the: author(s), publication year, country of origin, diet characteristics, animal model (rat or mouse), offspring gender (male or female), timing of paternal exposure to high-fat diet; and main outcomes regarding offspring health associated with the paternal high-fat diet. 
Due to the large variety in study designs, animal models, intervention techniques, and reported outcomes, this review focused on descriptive qualitative synthesis, as opposed to meta-analysis. An evaluation of article quality was performed using the ARRIVE (Animal Research: Reporting In Vivo Experiments) guidelines [16]. The selected articles were evaluated for adequacy in reporting according to the ARRIVE guidelines using a scoring system ( 0 - no; 1 - yes) on the 20 item checklist.

\section{RESULTS}

\section{Study characteristics}

Following study selection, sixteen articles were included in the review (Figure 1) [17-32]. Regarding the evaluation of offspring gender in examining the outcomes of paternal high-fat diets, six articles analyzed effects on both male and female offspring [20,22,24,26,31], six investigated only male offspring $[17,21,23,28,29,32]$, and four studied only female offspring $[18,25,29,30]$ (Table 1). With regard to the diets used in the studies, the composition of macronutrients (carbohydrate, protein, and fat) was different among studies evaluated [17-32]. The fat content varied widely in both the high-fat diets (22 to 62\%) and in the control diets (6 to $21 \%$ ). Worth noting, most studies using Sprague Dawley rats utilized a mix of SF03-020 and SF01-025 diets $[17,23,25,28,30]$. Three articles evaluating reproductive health changes used a high-fat diet consisting of $22 \%$ calories from fat [19-21], meanwhile, the studies evaluating metabolic impacts used high-fat diets consisting of more than $40 \%$ calories from fat [17,22-27,30,31].

A large range from 3 to 16 weeks was seen when examining the length of paternal exposure to the highfat diet among the studies. In a study involving only three weeks of high-fat diet exposure by Stanford and coauthors [31], detrimental effects on offspring health were observed, while a study including 13 weeks of exposure by Youngson and coauthors [28] did not observe any health changes in the offspring.

\section{Paternal high-fat diet exposure: effects on offspring health}

Paternal exposure to a high-fat diet induced adverse effects on offspring health in fourteen of the papers $(87 \%)$ considered in this review (Table 2). The main complications resulting in the offspring of both genders were: decreased glucose tolerance, insulin resistance, elevated serum adiponectin levels, decreased leptin gene expression, hepatic steatosis, and decreased reproductive function. These complications were observed in animals aged 7 to 52 weeks [20,22,24,26,27,31].

Specifically in male offspring, paternal exposure to a high-fat diet resulted in renal injury, increased triglycerides, cognitive impairments, growth deficits, and increased expression of lipogenic genes $[17,21,23,29,28,32]$. In studies specifically examining female offspring, increased risks of breast cancer, obesity, and diabetes, were all identified $[18,19,25,30]$.

Two of the studies evaluated offspring for changes in sperm microRNA methylation $[21,28]$, however, the results did not indicate any alterations associated with a paternal high-fat diet.

When examining the selected articles for compliance with ARRIVE guidelines (a checklist of information recommended for inclusion in publications describing in vivo experiments), the articles that comprise this revision included from 45 to $75 \%$ of the recommended items (Table 2 ). 


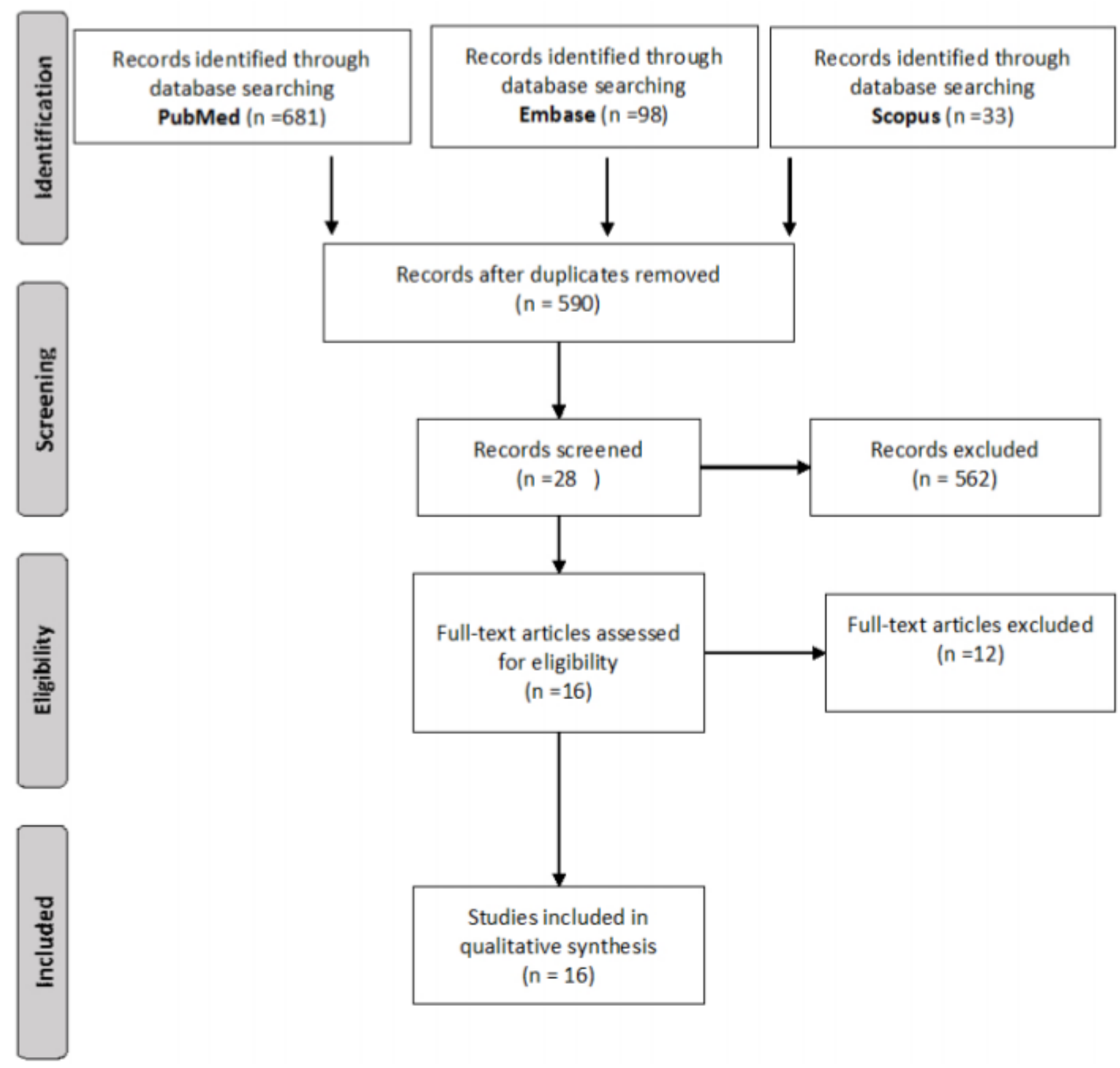

Figure 1. Flow chart of showing the process of selecting, including, and excluding articles for this review. 
Table 1. Characteristics and methodological aspects of the included studies

\begin{tabular}{|c|c|c|c|c|c|c|}
\hline Author / Year & $\begin{array}{l}\text { Time of Paterna } \\
\text { Exposure to Die }\end{array}$ & $\begin{array}{l}\text { Composition of } \\
\text { High-Fat Diet }\end{array}$ & $\begin{array}{l}\text { Composition of } \\
\text { Control Diet }\end{array}$ & $\begin{array}{l}\text { Offspring } \\
\text { Age / Gender }\end{array}$ & Species & Country \\
\hline $\begin{array}{l}\text { Chowdhury, S.S. } \\
\text { et al., } 2016 \text { [17] }\end{array}$ & $13-14$ weeks & $\begin{array}{l}\text { 40\% CHO, } 17 \% \text { PTN, 43\% FAT (SF03-020) } \\
39 \% \mathrm{CHO}, 17 \% \text { PTN, 44\% FAT (SF01-025) }\end{array}$ & $\begin{array}{l}65 \% \text { CHO, } 21 \% \text { PTN, } 12 \% \\
\text { FAT }\end{array}$ & 27 weeks $\hat{~}$ & $\begin{array}{l}\text { Sprague } \\
\text { Dawley Rat }\end{array}$ & Australia \\
\hline $\begin{array}{l}\text { Fontelles, C.C. et } \\
\text { al., } 2016[18]\end{array}$ & 9 weeks & $32 \%$ CHO, $19 \%$ PTN, $60 \%$ FAT (lard) & $\begin{array}{l}64 \% \mathrm{CHO}, 19 \% \text { PTN, } 16 \% \\
\text { FAT }\end{array}$ & 7 weeks $q$ & $\begin{array}{l}\text { Sprague } \\
\text { Dawley Rat }\end{array}$ & Brazil \\
\hline $\begin{array}{l}\text { Fullston, T. et al., } \\
2012[20]\end{array}$ & 10 weeks & 49\% CHO, 19\% PTN, 22\% FAT & $\begin{array}{l}64.7 \% \mathrm{CHO}, 19 \% \mathrm{PTN}, 6 \% \\
\text { FAT }\end{array}$ & 17 weeks $\hat{\partial}$ ㅇ & $\begin{array}{l}\text { C57BL/6 } \\
\text { mouse }\end{array}$ & Australia \\
\hline $\begin{array}{l}\text { Fullston, T. et al., } \\
2013 \text { [22] }\end{array}$ & 10 weeks & $\begin{array}{l}\text { 17\% PTN, } 40 \% \text { FAT ( } 21 \% \text { butter) (SF00- } \\
219 \text { ) }\end{array}$ & $\begin{array}{l}14 \% \text { PTN, } 21 \% \text { FAT } \\
\text { (6\% canola oil) (SF04-057) }\end{array}$ & $\begin{array}{l}8,14,26 \text {, and } \\
39 \text { weeks } \hat{O} q\end{array}$ & $\begin{array}{l}\text { C57BL/6 } \\
\text { mouse }\end{array}$ & Australia \\
\hline $\begin{array}{l}\text { Fullston, T. et al., } \\
2015[19]\end{array}$ & 8 weeks & $22 \%$ FAT (22\% clarified butter) & 6\% FAT (canola oil) & 8 weeks + & $\begin{array}{l}\text { C57BL/6 } \\
\text { mouse }\end{array}$ & Australia \\
\hline $\begin{array}{l}\text { Fullston, T. et al., } \\
2016[21]\end{array}$ & 10 weeks & 49.5\% CHO, 19\% PTN, 22\% FAT & $\begin{array}{l}65 \% \text { CHO, } 19 \% \text { PTN, } 6.3 \% \\
\text { FAT }\end{array}$ & 15 weeks $\hat{\jmath}$ & $\begin{array}{l}\text { C57BL/6 } \\
\text { mouse }\end{array}$ & Australia \\
\hline $\begin{array}{l}\text { Lecomte, V. et al., } \\
2016 \text { [23] }\end{array}$ & 13-14 weeks & $\begin{array}{l}40 \% \mathrm{CHO}, 17 \% \text { PTN, } 43 \% \text { FAT (SF03-020) } \\
39 \% \mathrm{CHO}, 17 \% \text { PTN, 44\% FAT (SF01-025) }\end{array}$ & $\begin{array}{l}65 \% \text { CHO, } 21 \% \text { PTN, } 12 \% \\
\text { FAT }\end{array}$ & $\begin{array}{l}8 \text { and } 42 \\
\text { weeks } \hat{~}\end{array}$ & $\begin{array}{l}\text { Sprague } \\
\text { Dawley Rat }\end{array}$ & Australia \\
\hline $\begin{array}{l}\text { Masuyama, H. et } \\
\text { al., } 2016 \text { [24] }\end{array}$ & 6 weeks & $20 \%$ CHO, $18 \%$ PTN, $62 \%$ LIP (lard) & $\begin{array}{l}61 \% \text { CHO, } 25 \% \text { PTN, } 13 \% \\
\text { FAT }\end{array}$ & 24 weeks $\hat{\sigma} q$ & ICR Mouse & Japan \\
\hline $\begin{array}{l}\text { McPherson, N.O. } \\
\text { et al., } 2014[29]\end{array}$ & 9 weeks & $\begin{array}{l}\text { 17\% PTN, } 40 \% \text { FAT (21\% butter) (SF00- } \\
219)\end{array}$ & $\begin{array}{l}14 \% \text { PTN, } 21 \% \text { FAT } \\
(6 \% \text { canola oil) (SF04-057) }\end{array}$ & 7 weeks $\widehat{\partial}$ & $\begin{array}{l}\text { C57BL/6 } \\
\text { mouse }\end{array}$ & Australia \\
\hline $\begin{array}{l}\mathrm{Ng}, \mathrm{S} . \mathrm{F} . \text { et al., } \\
2010[30]\end{array}$ & 8 weeks & $\begin{array}{l}40.7 \% \text { and } 43 \% \text { FAT (SF01-025, SF03- } \\
020)\end{array}$ & Not informed & 10 weeks & $\begin{array}{l}\text { Sprague } \\
\text { Dawley Rat }\end{array}$ & Australia \\
\hline $\begin{array}{l}\mathrm{Ng}, \text { S.F. et al., } \\
2014 \text { [25] }\end{array}$ & 11 weeks & $\begin{array}{l}40.7 \% \text { and } 43 \% \text { FAT (SF01-025, SF03- } \\
020)\end{array}$ & Not informed & 14 weeks & $\begin{array}{l}\text { Sprague } \\
\text { Dawley Rat }\end{array}$ & Australia \\
\hline $\begin{array}{l}\text { Ornellas, F. et al., } \\
2015[26]\end{array}$ & 8 weeks & $\begin{array}{l}32 \% \text { CHO, } 19 \% \text { PTN, } 49 \% \text { FAT } \\
\text { (17\% soybean oil, } 32 \% \text { lard) }\end{array}$ & $\begin{array}{l}64 \% \text { CHO, } 19 \% \text { PTN, } \\
17 \% \text { FAT }(17 \% \text { soybean oil) }\end{array}$ & 12 weeks $\hat{\sigma} \phi$ & $\begin{array}{l}\text { C57BL/6 } \\
\text { mouse }\end{array}$ & Brazil \\
\hline $\begin{array}{l}\text { Ornellas, F. et al., } \\
2016 \text { [27] }\end{array}$ & 8 weeks & $\begin{array}{l}32 \% \text { CHO, } 19 \% \text { PTN, } 49 \% \text { FAT } \\
\text { (36\% lard plus soybean oil) }\end{array}$ & $\begin{array}{l}64 \% \text { CHO, } 19 \% \text { PTN, } 17 \% \\
\text { FAT }\end{array}$ & 12 weeks $\hat{o}$ 우 & $\begin{array}{l}\text { C57BL/6 } \\
\text { mouse }\end{array}$ & Brazil \\
\hline $\begin{array}{l}\text { Stanford, K.I. et } \\
\text { al., } 2018[31]\end{array}$ & 3 weeks & $60 \%$ FAT & $21 \%$ FAT $(9 F 5020)$ & 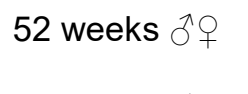 & $\begin{array}{l}\text { C57BL/6 } \\
\text { mice }\end{array}$ & EUA \\
\hline $\begin{array}{l}\text { Youngson, N.A. et } \\
\text { al., } 2016 \text { [28] }\end{array}$ & 13-16 weeks & $\begin{array}{l}40 \% \text { CHO, } 17 \% \text { PTN, } 43 \% \text { FAT (SF03-020) } \\
39 \% \text { CHO, } 17 \% \text { PTN, 44\% FAT (SF01-025) }\end{array}$ & $\begin{array}{l}65 \% \text { CHO, } 21 \% \text { PTN, } 12 \% \\
\text { FAT }\end{array}$ & 27 weeks $\widehat{\jmath}$ & $\begin{array}{l}\text { Sprague } \\
\text { Dawley Rat }\end{array}$ & Australia \\
\hline $\begin{array}{l}\text { Zhou, Y. et al., } \\
2018 \text { [32] }\end{array}$ & 10 weeks & $60 \%$ FAT (D12492) & $10 \%$ FAT (D12450B) & 8 weeks $\hat{0}$ & $\begin{array}{l}\text { C57BL/6J } \\
\text { mice }\end{array}$ & China \\
\hline
\end{tabular}

Legend: CHO - Carbohydrate; PTN - Protein; LIP - Fat; $\hat{O}$ - Males; + +- Females; ICR- Institute of Cancer Research 
Table 2. Offspring health consequences associated with paternal consumption of a high-fat diet

\begin{tabular}{lcll}
\hline Author / Year & $\begin{array}{c}\text { Final score } \\
\text { (ARRIVE) }\end{array}$ & \multicolumn{1}{c}{ Outcome (males) } & Outcome (females) \\
\hline $\begin{array}{l}\text { Chowdhury, S.S. } \\
\text { et al., 2016 [17] }\end{array}$ & $9 / 20$ & $\begin{array}{l}\text { Kidney injury, increased triglyceride } \\
\text { content, tubular damage, and absence of } \\
\text { brush border }\end{array}$ & $\begin{array}{l}{ }^{*} \text { This gender was not reported } \\
\text { on/examined in this study }\end{array}$ \\
$\begin{array}{l}\text { Fontelles, C.C. } \\
\text { et al., 2016 [18] }\end{array}$ & $12 / 20$ & $\begin{array}{l}{ }^{*} \text { This gender was not reported on/examined } \\
\text { in this study }\end{array}$ & Increased risk of breast cancer
\end{tabular}

Fullston, T. et al., $\quad 10 / 20$ 2012 [20]

Fullston, T. et al., 2013 [22]

Fullston, T. et al., 2015 [19]

Fullston, T. et al., 2016 [21]

Lecomte, $\mathrm{V}$. et al., 2016 [23]

Masuyama, $\mathrm{H}$. et $11 / 20$ al., 2016 [24]

McPherson, N.O. et al., 2014 [29]

$\mathrm{Ng}$, S.F. et al., 2010 [30]

$\mathrm{Ng}$, S.F. et al., 2014 [25]

Ornellas, F. et

Ornellas, F. et al., 2016 [27]

Stanford, K.I. et al., 2018 [31]

Youngson, N.A. et al., 2016 [28]

Zhou, Y. et al., $13 / 20$ al., 2015 [26]
Reduced sperm function, including reduced motility

Decreased glucose tolerance and altered insulin sensitivity

${ }^{*}$ This gender was not reported on/examined in this study

No changes in the sperm microRNA content of offspring

Growth deficit, reduced circulating levels of GH and IGF-I, decreased expression of growth markers in muscle (8 weeks), decreased expression of adipogenesis markers in adipose tissue, increased triglyceride content and expression of lipogenic genes in muscle

Increased HOMA IR, glucose, insulin, total triglycerides, and leptin, decreased serum levels of adiponectin, decreased adiponectin gene expression, and elevated leptin gene expression

Reduced sperm function, including reduced motility

*This gender was not reported on/examined in this study

${ }^{*}$ This gender was not reported on/examined in this study

Inflammation of the hypothalamus without increase in BM or food intake

Increased fasting glucose, decreased glucose tolerance, and hepatic steatosis

Impaired glucose tolerance, increased percentage of fat mass

No changes in the sperm microRNA content of offspring

Cognitive impairments
Reduced ovarian function and increased adiposity

Decreased glucose tolerance and altered insulin sensitivity

Accumulation of lipid droplets in ovaries and alterations in ovarian gene expression

*This gender was not reported on/examined in this study

*This gender was not reported on/examined in this study

Increased HOMA IR, glucose, insulin, total triglycerides, and leptin, decreased serum levels of adiponectin, decreased adiponectin gene expression, and elevated leptin gene expression

*This gender was not reported on/examined in this study

Early onset of impaired insulin secretion and glucose tolerance

Alterations in RpWAT gene expression and in the pancreatic islets, increased susceptibility to obesity and diabetes

Inflammation of the hypothalamus without increase in BM or food intake

Increased fasting glucose, decreased glucose tolerance, and hepatic steatosis

Impaired glucose tolerance, increased percentage of fat mass

*This gender was not reported on/examined in this study

*This gender was not reported on/examined in this study

Legend: mRNAs - Messenger RNA; GH - Growth Hormone; IGF-1 - Insulin Growth Factor 1; HOMA IR - Homeostatic Model Assessment for Insulin Resistance; RpWAT - Retroperitoneal White Adipose Tissue; BM - Body Mass

\section{DISCUSSION}

Given the significant impact that maternal periconceptional nutrition has been found to have on the development and life-long health of offspring, interest has also increased into exploring any potential influences paternal environmental manipulation may have on offspring development. According to the 
findings of this systematic review, paternal exposure to a high-fat diet induces adverse effects on the health of offspring (Table 2).

Human studies have associated being overweight with lower semen quality [33,34]. In general, these studies on males link being overweight to testicular oxidative stress and increased sperm ROS production. These findings reveal that obesity induces oxidative stress in the testis, thereby reducing sperm quality and, consequently, offspring health [14].

Paternal programming can be mediated through epigenetic mechanisms in sperm [14]. Such characteristics are transmitted through mechanisms involving DNA acetylation and methylation, as well as remodeling and microRNA expression. These epigenetic factors can alter gene expression at the transcriptional or post-transcriptional level [14,35].

Various possible mechanisms via which microRNAs may modulate gene expression during paternal programming are currently being investigated. One such hypothesis suggests that sperm microRNAs act as gene modulators, such that sperm microRNAs, which are transferred into the oocyte cytoplasm during fertilization, modulate gene expression during embryonic development and, thus, influence the health of the offspring [36].

\section{Metabolic complications}

The main consequences for the offspring associated with a paternal high-fat diet are correlated to metabolic health. Among the reviewed studies evaluating metabolic health, offspring displayed increased gene expression and serum levels of leptin, decreased gene expression and serum levels of adiponectin [2326], insulin resistance, glucose intolerance, hyperglycemia, hyperinsulinemia, changes in transcriptomes of pancreatic islet tissue (consistent with premature aging and chronic degenerative disorders in pancreatic islets) [22,24-26,30,31], and increased triglycerides and lipogenic gene expression [17,23,25].

Adiponectin is known to possess anti-inflammatory and antitumor effects, and plays an important role in several metabolic processes including the metabolism of carbohydrates and lipids [37]. Therefore, the decreased levels of adiponectin observed in these studies could be associated with several of the observed outcomes [17,23-26].

Increases in pro-inflammatory cytokines, along with decreases in adiponectin, favor the development of glucose intolerance and disorders related to insulin sensitivity [38,39]. Additionally, defects in the action and secretion of insulin lead to multiple metabolic changes, such as hyperglycemia, increased production of liver glucose, and dyslipidemia [39]. Furthermore, studies show that low levels of adiponectin are related with an increased incidence of cancer, suggesting an inverse correlation [40,41]. The mechanism underlying the increased incidence of breast cancer in the rat offspring of fathers exposed to a diet rich in saturated fat, seen in a study by Fontelles and coauthors [18], remains to be clearly elucidated. However, the results from this review, along with the other cited sources [38-41], suggest such a pathology could be associated with decreased expression and serum levels of adiponectin in the offspring.

Chowdhury and coauthors [17], investigating the effects of paternal exposure to a high-fat diet on kidney function in the offspring, observed increased levels of triglycerides in the kidneys and, consequently, renal injury. Renal disease is known to be related to kidney lipotoxicity and the accumulation of triglycerides in the kidney can be an early sign of organ complication [42].

\section{Growth and development}

Lecomte and coauthors [23] showed that the male offspring of rat fathers exposed to a high-fat diet demonstrated changes in their growth patterns, including reduced circulating levels of growth hormone $(\mathrm{GH})$ and IGF-I. Gene analysis on the 8 wk offspring from high-fat diet fathers revealed decreased expression levels of several key muscle growth markers: $\mathrm{GH}$ receptor (GHr), IGF-1, mammalian target of rapamycin (mTOR), and myogenic differentiation factor 1 (Myod1). These biomarkers play important roles in regulating growth during the pre- and postnatal periods by promoting the development of most body cells, especially muscle and cartilage cells [43].

\section{Reproductive disorders}

Impaired reproductive capacity has been observed in both male and female offspring of males exposed to a high-fat diet $[19,20,29]$. Female mouse offspring demonstrate reduced metabolic capacity, associated with an increased accumulation of lipid of droplets in the ovaries, and, consequently, reduced reproductive 
capacity. In contrast, the male mouse offspring demonstrated reduced reproductive capacity associated with alterations in sperm DNA acetylation, fertilization, and reduced sperm motility $[19,20,29]$.

\section{Diet Features}

It is worth noting that the type of fat included in the diet may influence the outcome. In a study investigating the risk of breast cancer in the offspring of rats exposed to high-fat diets, Fontelles and coauthors [18] found that the female offspring of males given a diet rich in saturated fat had an increased risk of developing breast cancer compared to the offspring of rats given a control diet. Meanwhile, the female offspring of rat fathers given a high-fat diet composed of polyunsaturated fats had a decreased risk of developing breast cancer compared to the control group.

In assessing the studies evaluating the effects of paternal exposure to a high-fat diet in both male and female offspring, we note that male offspring appear to be more affected than females, suggesting sexual dimorphism $[22,24,26]$, however, the reason for this is not well described in the literature.

Despite the special attention given to the quantity and quality of fats used in experimental diets, it is important to emphasize that the composition of macro- and micronutrients may have directly affected the results of the analyzed studies. In these studies, the percentage of protein in the high-fat diet was always greater than or equal to the percentage of protein in the control diet, while the percentage of carbohydrates was always lower than in the control diet.

\section{Limitations}

To the best of our knowledge, this review is the most comprehensive evaluation yet regarding the effects of paternal high-fat diets on health of the offspring. However, several limitations existed that should be considered. The database searches may have been limited by inclusion criteria requiring English-language publications. The ARRIVE guidelines, which are specific to experimental studies [16], were used to analyze the quality of selected papers. Most of the papers included in this review fulfilled at least $50 \%$ of the ARRIVE checklist guidelines. Most of the unfilled criteria involved missing facility descriptions, animal veterinary conditions, or descriptions of how a study's results may be translated to other species, including humans.

\section{CONCLUSION}

Dietary habits have the potential to cause repercussions in individuals as well as their offspring. The experimental studies analyzed here demonstrate several potential health consequences in offspring, mostly related to metabolic health, resulting from paternal exposure to a high-fat diet. As these complications have been found in experimental models, concern should be given to the consequences of paternal programming in humans, and, as such, the potential for preventing diseases in future generations through both male and female parents adhering to healthy eating habits prior to conception.

Funding: This research received no external funding.

Acknowledgments: M.S.G. elaborated on the initial full search strategy. M.S.G., L.J.D.F., and G.S.C. screened studies, assessed their quality, and extracted their data independently. M.S.G. wrote the manuscript and created all the tables and figures. L.S.S., J.M.B.M., and G.S.P. discussed and edited drafts of the manuscript. R.D.C reviewed the final version. All authors reviewed and approved the drafts of this paper. This research received no specific grant from any funding agency, commercial, or not-for-profit sectors. The authors would like to thank Dr. Gilson Teles Boaventura and Dr. Maria Ester Pereira da Conceição Machado for their help with revising the paper.

Conflicts of Interest: The authors declare no conflict of interest.

\section{REFERENCES}

1. Lee JY, Lee YR, Kim HR, Myong JP, Kang MY. Trends in Obesity Prevalence by Occupation Based on Korean National Health and Nutrition Examination Survey From 1998 to 2015. Saf Health Work. 2020;11(1):97-102.

2. Apovian CM. Obesity: definition, comorbidities, causes, and burden. Am J Manag Care. 2016;22(7 Suppl):s176851. Apovian CM. Obesity: definition, comorbidities, causes, and burden. Am. J. Manag. Care. 2016;22(7 Suppl):s176-85.

3. Hillier TA, et al., Childhood obesity and metabolic imprinting: the ongoing effects of maternal hyperglycemia. Diabetes Care, 2007. 30(9): p. 2287-92.10.2337/dc06-2361.

4. Wang, G., et al., Epigenetics and early life origins of chronic noncommunicable diseases. J Adolesc Health, 2013. 52(2 Suppl 2): p. S14-21.10.1016/j.jadohealth.2012.04.019. 
5. Zhang YP, et al., Maternal High Fat Diet Acts on the Brain to Induce Baroreflex Dysfunction and Sensitization of Angiotensin II-Induced Hypertension in Adult Offspring. Am J Physiol Heart Circ Physiol, 2018. 10.1152/ajpheart.00698.2017.10.1152/ajpheart.00698.2017.

6. Raad G et al., Paternal obesity: how bad is it for sperm quality and progeny health? Basic Clin Androl. 2017;27:20.

7. Binder NK et al. Paternal obesity in a rodent model affects placental gene expression in a sex-specific manner. Reproduction. 2015;149(5):435-44.

8. Binder NK, Mitchell M, Gardner DK. Parental diet-induced obesity leads to retarded early mouse embryo development and altered carbohydrate utilisation by the blastocyst. Reprod. Ferti.I Dev. 2012;24(6):804-12.

9. Fullston T et al. Female offspring sired by diet induced obese male mice display impaired blastocyst development with molecular alterations to their ovaries, oocytes and cumulus cells. J. Assist. Reprod. Genet. 2015;32(5):72535.

10. McPherson NO, Bell VG, Zander-Fox DL, Fullston T, Wu LL, Robker RL, et al. When two obese parents are worse than one! Impacts on embryo and fetal development. Am J Physiol Endocrinol Metab. 2015;309(6):E568-81.

11. Chen YP, Xiao XM, Li J, Reichetzeder C, Wang ZN, Hocher B. Paternal body mass index (BMI) is associated with offspring intrauterine growth in a gender dependent manner. PLoS One. 2012;7(5):e36329.

12. Schagdarsurengin $U$, Steger K. Epigenetics in male reproduction: effect of paternal diet on sperm quality and offspring health. Nat Rev Urol. 2016;13(10):584-95.

13. Braun JM, Messerlian C, Hauser R, Fathers Matter: Why It's Time to Consider the Impact of Paternal Environmental Exposures on Children's Health. Curr. Epidemiol. Rep, 2017. 4(1): p. 46-55.10.1007/s40471-017-0098-8.

14. Guerrero-Bosagna C, Skinner MK. Environmental epigenetics and effects on male fertility. Adv. Exp. Med. Biol. 2014;791:67-81.

15. Moher $\mathrm{D}$ et al., Reprint--preferred reporting items for systematic reviews and meta-analyses: the PRISMA statement. Phys Ther, 2009. 89(9):873-80, http://www.ncbi.nlm.nih.gov/pubmed/19723669.

16. Kilkenny $\mathrm{C}$ et al., Improving bioscience research reporting: the ARRIVE guidelines for reporting animal research. Osteoarthritis Cartilage, 2012. 20(4):256-60.10.1016/j.joca.2012.02.010.

17. Chowdhury SS et al., Paternal High Fat Diet in Rats Leads to Renal Accumulation of Lipid and Tubular Changes in Adult Offspring. Nutrients, 2016. 8(9).10.3390/nu8090521.

18. Fontelles $\mathrm{CC}$ et al., Paternal programming of breast cancer risk in daughters in a rat model: opposing effects of animal- and plant-based high-fat diets. Breast Cancer Res, 2016;18(1):71. 10.1186/s13058-016-0729-x.

19. Fullston $T$, et al., Female offspring sired by diet induced obese male mice display impaired blastocyst development with molecular alterations to their ovaries, oocytes and cumulus cells. J. Assist. Reprod. Genet., 2015;32(5):72535.10.1007/s10815-015-0470-x.

20. Fullston $T$ et al., Diet-induced paternal obesity in the absence of diabetes diminishes the reproductive health of two subsequent generations of mice. Hum. Reprod., 2012.27(5):1391-400.10.1093/humrep/des030.

21. Fullston T et al., Sperm microRNA Content Is Altered in a Mouse Model of Male Obesity, but the Same Suite of microRNAs Are Not Altered in Offspring's Sperm. PLoS One, 2016;11(11):e0166076. 10.1371/journal.pone.0166076.

22. Fullston $T$ et al., Paternal obesity initiates metabolic disturbances in two generations of mice with incomplete penetrance to the $\mathrm{F} 2$ generation and alters the transcriptional profile of testis and sperm microRNA content. FASEB J, 2013;27(10):4226-43.10.1096/fj.12-224048.

23. Lecomte $\mathrm{V}$ et al., Effects of paternal obesity on growth and adiposity of male rat offspring. Am. J. Physiol. Endocrinol. Metab, 2017;312(2):E117-25. 10.1152/ajpendo.00262.2016

24. Masuyama $\mathrm{H}$ et al., The effects of paternal high-fat diet exposure on offspring metabolism with epigenetic changes in the mouse adiponectin and leptin gene promoters. Am. J. Physiol. Endocrinol. Metab. 2016;311(1):E236-45. 10.1152/ajpendo.00095.2016.

25. Ng SF et al., Paternal high-fat diet consumption induces common changes in the transcriptomes of retroperitoneal adipose and pancreatic islet tissues in female rat offspring. FASEB J, 2014. 28(4): p. 1830-41.10.1096/fj.13-244046

26. Ornellas $\mathrm{F}$ et al., Programming of obesity and comorbidities in the progeny: lessons from a model of diet-induced obese parents. PLoS One, 2015;10(4):e0124737. 10.1371/journal.pone.0124737.

27. Ornellas $\mathrm{F}$ et al., Combined parental obesity augments single-parent obesity effects on hypothalamus inflammation, leptin signaling (JAK/STAT), hyperphagia, and obesity in the adult mice offspring. Physiol. Behav., 2016;153:4755.10.1016/j.physbeh.2015.10.019.

28. Youngson NA et al., Obesity-induced sperm DNA methylation changes at satellite repeats are reprogrammed in rat offspring. Asian. J. Androl. 2016;18(6):930-6.10.4103/1008-682X.163190.

29. McPherson NO et al. Obese father's metabolic state, adiposity, and reproductive capacity indicate son's reproductive health. Fertil Steril. 2014;101(3):865-73. 
30. Ng SF et al. Chronic high-fat diet in fathers programs beta-cell dysfunction in female rat offspring. Nature. 2010;467(7318):963-6.

31. Stanford KI et al. Paternal Exercise Improves Glucose Metabolism in Adult Offspring. Diabetes. 2018;67(12):253040.

32. Zhou $Y$ et al. Diet-Induced Paternal Obesity Impairs Cognitive Function in Offspring by Mediating Epigenetic Modifications in Spermatozoa. Obesity (Silver Spring). 2018;26(11):1749-57.

33. Campbell JM et al., Paternal obesity negatively affects male fertility and assisted reproduction outcomes: a systematic review and meta-analysis. Reprod Biomed Online. 2015;31(5):593-604.

34. Rato L et al, High-energy diets: a threat for male fertility? Obes Rev. 2014;15(12):996-1007.

35. Dupont $\mathrm{C}$ et al., Role of miRNA in the Transmission of Metabolic Diseases Associated With Paternal Diet-Induced Obesity. Front Genet. 2019;10:337.

36. Yamauchi Y, Shaman JA, Ward WS, Non-genetic contributions of the sperm nucleus to embryonic development. Asian J Androl, 2011;13(1):31-5. 10.1038/aja.2010.75.

37. Lihn AS, Pedersen SB, Richelsen B, Adiponectin: action, regulation and association to insulin sensitivity. Obes. Rev.2005;6(1):13-21. 10.1111/j.1467-789X.2005.00159.x.

38. Fontelles $\mathrm{CC}$ et al., Paternal programming of breast cancer risk in daughters in a rat model: opposing effects of animal- and plant-based high-fat diets, in Breast Cancer Res. 2016: London.

39. Bardini G, Rotella CM, Giannini S, Dyslipidemia and diabetes: reciprocal impact of impaired lipid metabolism and Beta-cell dysfunction on micro- and macrovascular complications. Rev. Diabet. Stud. 2012;9(2-3):8293.10.1900/RDS.2012.9.82

40. Nigro $\mathrm{E}$ et al., Adiponectin and colon cancer: evidence for inhibitory effects on viability and migration of human colorectal cell lines. Mol. Cell. Biochem. 2018. 10.1007/s11010-018-3319-7.10.1007/s11010-018-3319-7

41. Kojima R, et al., Association of Adiponectin With Cancer and All-Cause Mortality in a Japanese CommunityDwelling Elderly Cohort: A Case-Cohort Study. J Epidemiol, 2018. 10.2188/jea.JE20170087.10.2188/jea.JE20170087.

42. Lee HS, Mechanisms and consequences of hypertriglyceridemia and cellular lipid accumulation in chronic kidney disease and metabolic syndrome. Histol Histopathol, 2011;26(12):1599-610. 10.14670/HH-26.1599.

43. Wu S, Yang W, De Luca F, Insulin-Like Growth Factor-Independent Effects of Growth Hormone on Growth Plate Chondrogenesis and Longitudinal Bone Growth. Endocrinol., 2015;156(7):2541-51. 10.1210/en.2014-1983.

(C) 2021 by the authors. Submitted for possible open access publication under the terms and conditions of the Creative Commons Attribution (CC BY NC) license (https://creativecommons.org/licenses/by-nc/4.0/). 